\title{
Cecembia lonarensis gen. nov., sp. nov., a haloalkalitolerant bacterium of the family Cyclobacteriaceae, isolated from a haloalkaline lake and emended descriptions of the genera Indibacter, Nitritalea and Belliella
}

Correspondence

S. Shivaji

shivas@ccmb.res.in

\author{
P. Anil Kumar, ${ }^{1}$ T. N. R. Srinivas, ${ }^{1}$ S. Madhu, ${ }^{1}$ R. Sravan, ${ }^{1}$ Shashi Singh, ${ }^{1}$ \\ S. W. A. Naqvi, ${ }^{2}$ S. Mayilraj ${ }^{3}$ and S. Shivaji ${ }^{1}$
}

${ }^{1}$ Centre for Cellular and Molecular Biology, Uppal Road, Hyderabad 500 007, India

${ }^{2}$ National Institute of Oceanography, Dona Paula, Goa 403004, India

${ }^{3}$ Microbial Type Culture Collection \& Gene Bank (MTCC), Institute of Microbial Technology, Chandigarh 160036, India

\begin{abstract}
A novel Gram-staining-negative, rod-shaped, non-motile bacterium, designated strain $\mathrm{LW}^{\top}{ }^{\top}$, was isolated from a water sample collected from Lonar Lake of Buldhana district, Maharashtra, India. Colonies and broth cultures were reddish orange due to the presence of carotenoid pigments. Strain LW9 ${ }^{\top}$ was positive for catalase, ornithine decarboxylase and lysine decarboxylase activities and negative for gelatinase, oxidase, urease and lipase activities. The predominant fatty acids were iso- $\mathrm{C}_{15: 0}(31.3 \%)$, iso- $\mathrm{C}_{16: 0}(9.3 \%)$, anteiso- $\mathrm{C}_{15: 0}(7.3 \%)$, iso- $\mathrm{C}_{16: 1} \mathrm{H}(6.1 \%)$, summed feature 3 (comprising $\mathrm{C}_{16: 1} \omega 7 c / \mathrm{C}_{16: 1} \omega 6 c ; 5.9 \%$ ), iso- $\mathrm{C}_{17: 1} \omega 9 c(5.4 \%)$ and iso- $\mathrm{C}_{17: 0} 3-\mathrm{OH}$ (5.0\%). Strain $\mathrm{LW}^{\top}$ contained $\mathrm{MK}-7$ as the major respiratory quinone. The polar lipids consisted of phosphatidylethanolamine, two unidentified aminolipids and seven unidentified lipids. The DNA $\mathrm{G}+\mathrm{C}$ content of strain $\mathrm{LW}^{\top}$ was 40.5 mol\%. 16S rRNA gene sequence analysis indicated that the type strains of Indibacter alkaliphilus and Aquiflexum balticum, two members of the family Cyclobacteriaceae (phylum 'Bacteroidetes') were the most closely related strains with sequence similarities of 93.0 and $94.0 \%$, respectively. Other members of the family Cyclobacteriaceae showed sequence similarities $<93.0 \%$. Based on these phenotypic characteristics and on phylogenetic inference, strain $L W 9^{\top}$ is proposed as the representative of novel species in a new genus, Cecembia lonarensis gen. nov., sp. nov. The type strain of the type species, Cecembia lonarensis, is $\mathrm{LW9}^{\top}$ (=CCUG $58316^{\top}=\mathrm{KCTC} 22772^{\mathrm{T}}$ ). Emended descriptions of the genera Indibacter, Nitritalea and Belliella are also proposed.
\end{abstract}

The family Cyclobacteriaceae (a member of the class Cytophagia, phylum 'Bacteroidetes') was recently proposed (Ludwig et al., 2008) to include the type genus Cyclobacterium (Raj \& Maloy, 1990; Nedashkovskaya et al., 2005; Ying et al., 2006) and the recently described genera Algoriphagus, Aquiflexum, Belliella, Chimaereicella, Echinicola, Hongiella, Indibacter and Nitritalea. Species belonging to the genera Chimaereicella and Hongiella were transferred to the genus Algoriphagus on the basis of polyphasic taxonomy analyses (Nedashkovskaya et al., 2004, 2007).

Abbreviation: $\mathrm{PE}$, phosphatidylethanolamine.

The GenBank/EMBL/DDBJ accession number for the 16S rRNA gene sequence of strain $\mathrm{LW}^{\top}$ is FN393747.

A supplementary figure is available with the online version of this paper.
Members of the family Cyclobacteriaceae have been recovered from a wide variety of habitats, such as marine surface water (Brettar et al., 2004a, b), sediment from an oilfield (Ying et al., 2006), a sea urchin (Nedashkovskaya et al., 2006), alkaline ground water, coral, marine sediments and soil (Nedashkovskaya et al., 2007; Yoon et al., 2006), microbial mats from Antarctic lakes (Van Trappen et al., 2004), a freshwater lake (Liu et al., 2009), brown and green algae and tidal flat sediment (Nedashkovskaya et al., 2004), a salt water lagoon (Copa-Patiño et al., 2008), a marine solar saltern (Yoon et al., 2005) and sea ice (Bowman et al., 2003).

Strain $\mathrm{LW}^{\mathrm{T}}$ was isolated from a water sample collected at a depth of $4.5 \mathrm{~m}$ from the haloalkaline Lonar Lake, located near Lonar town, Buldhana district, Maharashtra, India 
$\left(19^{\circ} 58^{\prime} \mathrm{N} 76^{\circ} 30^{\prime} \mathrm{E}\right)$ on 25th August 2008. The sample that yielded strain $\mathrm{LW} 9^{\mathrm{T}}$ had a $\mathrm{pH}$ of 10 . For isolation of bacteria, a $100 \mu \mathrm{l}$ water sample was plated on ZoBell marine agar (ZoBell, 1941) adjusted to $\mathrm{pH} 10.0$ with a sodium carbonate solution $(20 \%, \mathrm{w} / \mathrm{v})$ and incubated at room temperature for 15 days. The total viable bacterial count (per ml water) obtained was approximately 4.0 to $6.0 \times 10^{5}$. Out of the two reddish orange coloured colonies that shared $100 \% 16 \mathrm{~S}$ rRNA sequence similarity, one was selected and characterized. For $16 \mathrm{~S}$ rRNA gene sequencing, DNA was prepared using a microbial DNA isolation kit (Mo Bio Laboratories) and sequenced as described previously (Lane, 1991). The resultant almost complete sequence of the 16S rRNA gene (1513 nt) was subjected to a BLAST sequence similarity search (Altschul et al., 1990) and EzTaxon (Chun et al., 2007) was used to identify the nearest taxa. All 16S rRNA gene sequences of members of the family Cyclobacteriaceae were downloaded from the database (http://www.ncbi.nlm.nih.gov) and aligned using the program CLUSTAL_X (Thompson et al., 1997); the alignment was then corrected manually. Phylogenetic trees were constructed using the maximum-likelihood and neighbour-joining methods (Saitou \& Nei, 1987) using the program PhyML (Guindon et al., 2005) and the PHYLIP package, version 3.5 (Felsenstein, 1993), respectively. The resultant tree topologies were evaluated by bootstrap analysis based on 1000 resamplings using the SEQBOOT and CONSENSE programs in the PHYLIP package. Pairwise evolutionary distances were computed using the DNADIST program with Kimura's two-parameter model as developed by Kimura (1980).

Strain $\mathrm{LW} 9^{\mathrm{T}}$ shared the highest $16 \mathrm{~S}$ rRNA gene sequence similarity with Indibacter alkaliphilus $\mathrm{LW}^{\mathrm{T}}(94 \%)$ and Aquiflexum balticum BA160 ${ }^{\mathrm{T}}$ (93\%). Phylogenetic analysis further indicated that strain $\mathrm{LW} 9^{\mathrm{T}}$ clustered with $I$. alkaliphilus forming a distinct branch in the family Cyclobacteriaceae on the neighbour-joining tree (Fig. 1). The topology of the maximum-likelihood tree was similar (data not shown). Both phylogenetic trees showed that the type strains of A. balticum, Nitritalea halalkaliphila and Belliella baltica were the next closest neighbours of strain LW9 ${ }^{\mathrm{T}}$. Hence, the type strains of I. alkaliphilus, A. balticum, $N$. halalkaliphila and B. baltica were grown under the same conditions as strain $\mathrm{LW} 9^{\mathrm{T}}$ and used as reference strains in most phenotypic tests.

Cell morphology and motility were studied using a light microscope. Motility was assessed on trypticase soy agar (TSA) medium containing $\left(1^{-1}\right)$ pancreatic digest of casein $(17 \mathrm{~g})$, papaic digest of soyabean meat $(3 \mathrm{~g}), \mathrm{NaCl}(5 \mathrm{~g})$, dipotassium hydrogen phosphate $(2.5 \mathrm{~g})$, glucose $(2.5 \mathrm{~g})$ and agar $(4.0 \mathrm{~g})$. For assessment of colony morphology, the culture was grown on half-strength marine agar. Growth at $4,10,18,30,37$ and $40{ }^{\circ} \mathrm{C}$ was ascertained using ZoBell marine agar medium and salt tolerance [at 0 (without $\mathrm{NaCl}), 1,2,3,4,5,6,8$ and $10 \%(\mathrm{w} / \mathrm{v}) \mathrm{NaCl}]$ was ascertained using nutrient agar (NA) medium containing $\left(1^{-1}\right)$ peptone $(5 \mathrm{~g})$, beef extract $(3 \mathrm{~g})$ and agar $(20 \mathrm{~g})$.
Biochemical characteristics such as oxidase, lysine decarboxylase and ornithine decarboxylase activities, nitrate reduction, hydrolysis of aesculin, gelatin, ONPG, starch, Tween 60 and Tween 80, carbon source assimilation, $\mathrm{H}_{2} \mathrm{~S}$ production and sensitivity to 32 different antibiotics using the disc diffusion method with commercially available discs (HiMedia) were determined by previously described methods (Lányí, 1987; Smibert \& Krieg, 1994). Anaerobic growth was assessed in screw-capped tubes containing ZoBell marine broth with $0.05 \%$ sodium ascorbate filled up to the top of the tube without an air gap. Biochemical characteristics were also assessed using the Hi25 Enterobacteriaceae identification kit (cat. no. KB003) and the HiCarbohydrate kit parts A, B and C (cat. no. KB009) (HiMedia) according to the manufacturer's protocol. Growth at $\mathrm{pH}$ 5.0, 6.0, 7.0, 7.5, 8.0, 8.5, 9.0, 9.5, $10.0,11.0$ and 12.0 was assessed on TSA buffered with citric acid/NaOH (for pH 5.0 and 6.0), $\mathrm{NaHPO}_{4} /$ $\mathrm{Na}_{2} \mathrm{HPO}_{4}$ (for $\mathrm{pH}$ 7.0-8.0), glycine/ $\mathrm{NaOH}$ (for $\mathrm{pH} 9.0-$ 10.0) or Tris (for $\mathrm{pH} 11.0$ and 12.0). The phenotypic characteristics of strain $\mathrm{LW}^{\mathrm{T}}$ are listed in the genus and species descriptions and in Table 1.

For pigment extraction, $2 \mathrm{ml}$ culture of exponential phase cells grown in ZoBell marine broth was centrifuged, the supernatant was discarded, $2 \mathrm{ml}$ ethanol was added, and the mixture was mixed thoroughly on a vortex mixer. Following centrifugation, the supernatant was transferred to a new centrifuge tube. The absorption spectrum was measured at 300-800 $\mathrm{nm}$ on a Lambda 35 spectrometer (Perkin Elmer) using ethanol as a blank.

For cellular fatty acid analysis, strain LW9 ${ }^{\mathrm{T}}$, I. alkaliphilus LW1 ${ }^{\mathrm{T}}$, A. balticum DSM $16537^{\mathrm{T}}$, B. baltica DSM $15883^{\mathrm{T}}$ and $N$. halalkaliphila $\mathrm{LW}^{\mathrm{T}}$ were grown on TSA at $30{ }^{\circ} \mathrm{C}$ for $48 \mathrm{~h}$. Cellular fatty acid methyl esters were obtained from cells by saponification, methylation and extraction following the protocol of MIDI. Cellular fatty acid methyl esters were separated by GC (6850) and identified and qualified with MIDI System software (version.4.0, using the aerobe TSBA50 method and TSBA50 database). Polar lipids were extracted following the method of Bligh \& Dyer (1959) and analysed by two-dimensional TLC followed by spraying with appropriate detection reagents (Komagata \& Suzuki, 1987). Menaquinones were extracted as described by Collins et al. (1977) and analysed by HPLC (Groth et al., 1997). Menaquinones and polar lipids were analysed on freeze-dried cells of strain $\mathrm{LW}^{\mathrm{T}}$ and the four reference strains. DNAs of strain $\mathrm{LW}^{\mathrm{T}}$, I. alkaliphilus $\mathrm{LW}^{\mathrm{T}}, A$. balticum DSM $16537^{\mathrm{T}}$, N. halalkaliphila $\mathrm{LW}^{\mathrm{T}}$ and $B$. baltica DSM $15883^{\mathrm{T}}$ were isolated according to the procedure of Marmur (1961) and the $\mathrm{G}+\mathrm{C}$ content was determined from melting point $\left(T_{\mathrm{m}}\right)$ curves (Sly et al., 1986) obtained by using a Lambda 2 UV-Vis spectrophotometer (Perkin Elmer) equipped with the Templab 2.0 software package (Perkin Elmer). Escherichia coli strain DH5- $\alpha$ DNA was used as a standard in determining the DNA G $+\mathrm{C}$ content. 


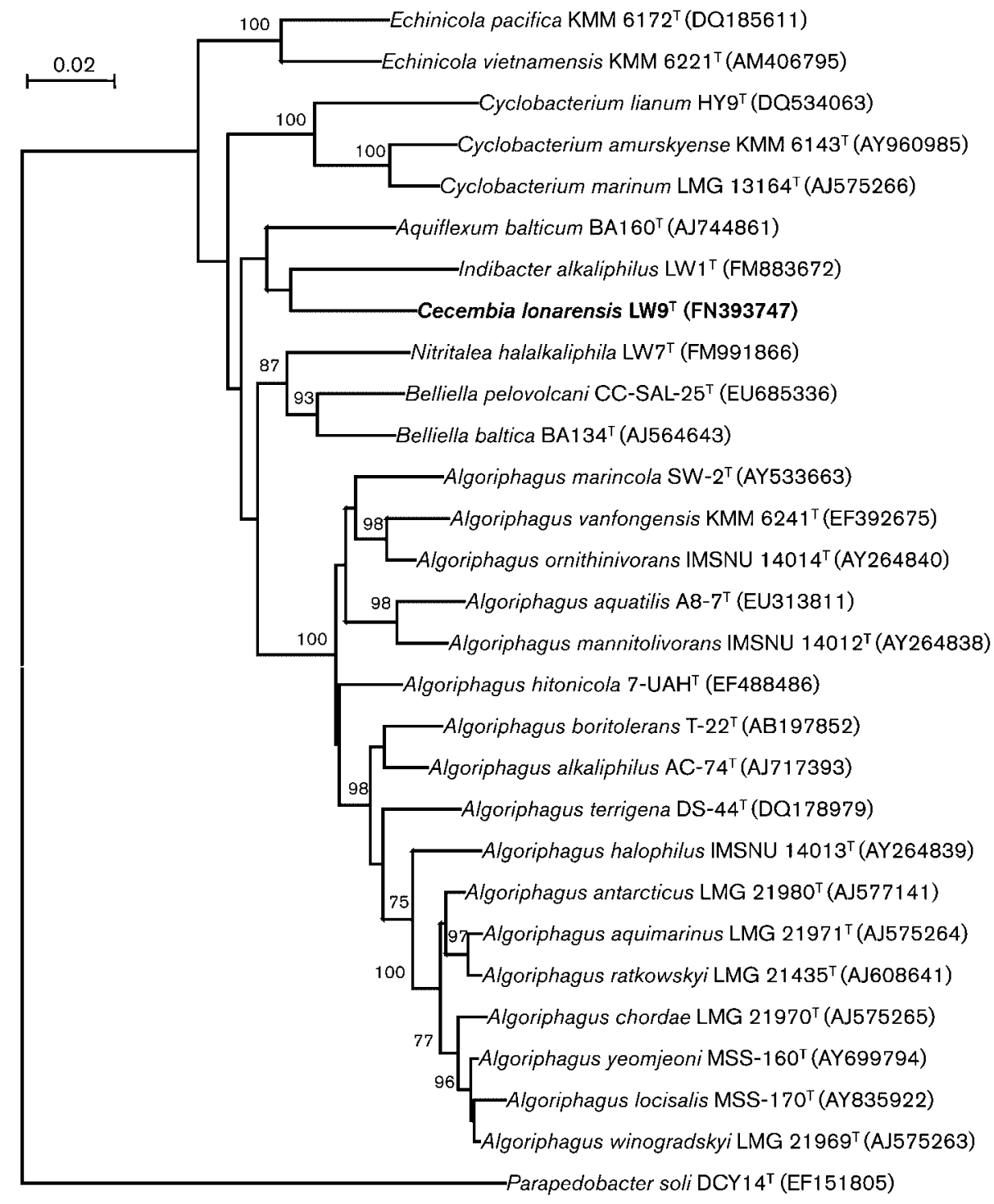

Fig. 1. Neighbour-joining phylogenetic tree based on 16S rRNA gene sequences showing the relationship of Cecembia lonarensis $\mathrm{LW}^{\top}$ with members of the family Cyclobacteriaceae. Numbers at nodes are bootstrap values $>70 \%$. Parapedobacter soli DCY $14^{\top}$ was used as an outgroup. Bar, 0.02 substitutions per nucleotide position.

The absorption spectrum of the ethanol extract of strain $\mathrm{LW} 9^{\mathrm{T}}$ showed a broad peak with a maximum around $475 \mathrm{~nm}$, which is typical for carotenoid pigments (Asker et al., 2007). Alkalinization of the extract did not cause a bathychromatic shift of the peak indicating the absence of flexirubin-type pigments, as often observed for marine members of the phylum 'Bacteroidetes' (Brettar et al., 2004a, b; Yi \& Chun, 2004). The cellular fatty acid composition of strain $\mathrm{LW} 9^{\mathrm{T}}$ showed a pronounced dominance of the branched saturated fatty acids iso- $\mathrm{C}_{15: 0}$, iso- $\mathrm{C}_{16: 0}$, anteiso- $\mathrm{C}_{15: 0}$, iso- $\mathrm{C}_{17: 0} 3-\mathrm{OH}$ and the unsaturated fatty acids iso- $\mathrm{C}_{16: 1} \mathrm{H}$, summed feature 3 (comprising $\mathrm{C}_{16: 1} \omega 7 \mathrm{cl}$ $\mathrm{C}_{16: 1} \omega 6 c$ ) and iso- $\mathrm{C}_{17: 1} \omega 9 c$ (Table 2). Thus, the fatty acid composition of strain $\mathrm{LW}^{\mathrm{T}}$ differed from those of the four reference strains (Table 2). Strain $\mathrm{LW}^{\mathrm{T}}$ had menaquinone MK-7 as respiratory quinone, which is similar to I. alkaliphilus $\mathrm{LW} 1^{\mathrm{T}}, B$. baltica DSM $15883^{\mathrm{T}}$ and $N$. halalkaliphila $\mathrm{LW}^{\mathrm{T}}$. Polar lipids of strain $\mathrm{LW}^{\mathrm{T}}$ were phosphatidylethanolamine (PE), two unidentified aminolipids (AL1, AL2) and seven unidentified lipids (L1-L7) (Fig. S1). The reference strains also possessed PE and some unknown lipids. In addition to PE, I. alkaliphilus $\mathrm{LW} 1^{\mathrm{T}}$ possessed one unidentified aminolipid (AL3) and five unidentified lipids (L1, L8-L11), N. halalkaliphila $\mathrm{LW7}^{\mathrm{T}}$ possessed one unidentified aminolipid (AL3), two unidentified phospholipids (PL1, PL2) and six unidentified lipids (L1, L2, L5-L7, L12), and B. baltica DSM $15883^{\mathrm{T}}$ possessed two unidentified phospholipids (PL1, PL3) and nine 
Table 1. Characteristics that differentiate Cecembia lonarensis gen. nov., sp. nov., from closely related members of the family Cyclobacteriaceae

Strains: 1, Cecembia lonarensis $\mathrm{LW}^{\mathrm{T}} ; 2$, Indibacter alkaliphilus $\mathrm{LW}^{\mathrm{T}}$; 3, Aquiflexum balticum DSM $16537^{\mathrm{T}}$; 4, Nitritalea halalkaliphila $\mathrm{LW}^{\mathrm{T}}$; 5 , Belliella baltica DSM $15883^{\mathrm{T}}$. Data for all strains are from the present study except for DNA G $+C$ content of A. balticum DSM $16537^{\mathrm{T}}$ (Brettar et al., 2004b) and B. baltica DSM $15883^{\mathrm{T}}$ (Brettar et al., 2004a). All strains are positive for catalase activity, and utilization of xylose, glucose, fructose, lactose and mannose. All strains are negative for phenylalanine deaminase activity, methyl red and Voges-Proskauer reactions, indole production, agar and urea hydrolysis and utilization of sodium gluconate, dulcitol, sorbitol, mannitol, methyl $\alpha$-D-glucoside, ribose, xylitol, sorbose and glycerol. + , Positive; -, negative; w, weak positive reaction. All taxa contain $\mathrm{PE}$ as major phospholipid.

\begin{tabular}{|lccccc|}
\hline Characteristic & $\mathbf{1}$ & $\mathbf{2}$ & $\mathbf{3}$ & $\mathbf{4}$ & $\mathbf{5}$ \\
\hline $\mathrm{pH}$ growth range & $7.5-10.0$ & $7.5-12.0$ & $7-9$ & $7.5-12.0$ & $6-10$ \\
NaCl tolerance & $0-4$ & $0-8$ & $0-6$ & $1-22$ & $0-6$ \\
(\% w/v) & & & & & \\
Oxidase & - & + & + & + & + \\
Lysine & + & + & - & + & - \\
decarboxylase & & & & & \\
Ornithine & + & + & - & + & - \\
decarboxylase & & & & & \\
Nitrate reduction & - & + & + & - & + \\
Hydrolysis of: & & & & & \\
Aesculin & - & + & + & - & + \\
Gelatin & - & - & + & + & - \\
ONPG & - & - & + & + & + \\
Starch & - & + & + & - & - \\
Utilization of: & & & & & \\
Citrate & + & - & + & + & - \\
Malonate & + & - & + & + & - \\
D-Arabinose & + & + & - & - & + \\
L-Arabinose & + & + & - & - & + \\
Adonitol & + & + & - & - & - \\
Rhamnose & + & + & - & - & - \\
Cellobiose & + & + & - & + & + \\
Melibiose & + & + & - & + & + \\
Melezitose & - & - & - & - & + \\
Raffinose & + & + & - & + & + \\
Trehalose & - & + & - & + & + \\
Maltose & + & + & - & - & + \\
Galactose & - & + & - & - & + \\
Sucrose & + & + & - & + & + \\
Glucosamine & - & + & - & - & - \\
Methyl $\alpha-D-$ & - & - & - & - & + \\
$\quad$ mannoside & & & & & \\
Inositol & - & - & + & + & - \\
Inulin & - & - & - & - & + \\
Salicin & - & - & - & - & + \\
DNA G $+\mathrm{C}$ & 40.5 & 43 & 38.4 & 49 & 35.4 \\
content (mol\%) & & & & & \\
\hline
\end{tabular}

Table 2. Fatty acid compositions of Cecembia lonarensis gen. nov., sp. nov., and related members of the family Cyclobacteriaceae

Strains: 1, Cecembia lonarensis $\mathrm{LW}^{\mathrm{T}} ; 2$, Indibacter alkaliphilus $\mathrm{LW1}^{\mathrm{T}}$; 3, Aquiflexum balticum DSM $16537^{\mathrm{T}} ; 4$, Nitritalea halalkaliphila LW7 $7^{\mathrm{T}} ; 5$, Belliella baltica DSM $15883^{\mathrm{T}}$. Results are presented as a percentage of the total fatty acids. Fatty acids amounting to $5 \%$ or more of the total fatty acids are in bold. Data for all taxa are from the present study. The five strains were grown on TSA at $30^{\circ} \mathrm{C}$ for two days. Tr, Trace $(<1 \%)$; ND, not detected.

\begin{tabular}{|c|c|c|c|c|c|}
\hline Fatty acid & 1 & 2 & 3 & 4 & 5 \\
\hline $\mathrm{C}_{14: 0}$ & $\mathrm{ND}$ & ND & 2.9 & $\operatorname{Tr}$ & $\mathrm{ND}$ \\
\hline iso- $\mathrm{C}_{14: 0}$ & 1.1 & $\mathrm{ND}$ & 1.8 & $\operatorname{Tr}$ & $\mathrm{ND}$ \\
\hline iso- $\mathrm{C}_{15: 0} \mathrm{G}$ & 2.4 & $\mathrm{ND}$ & ND & $\mathrm{ND}$ & 8.7 \\
\hline iso- $\mathrm{C}_{15: 0}$ & 31.3 & 47.0 & 15.6 & 59.6 & 21.1 \\
\hline anteiso- $C_{15: 0}$ & 7.3 & 7.6 & 61.0 & 3.1 & 3.8 \\
\hline $\mathrm{C}_{15: 0} 3-\mathrm{OH}$ & 2.8 & 3.7 & ND & ND & 2.1 \\
\hline iso- $\mathrm{C}_{15: 0} 3-\mathrm{OH}$ & ND & 2.1 & ND & 2.1 & 2.9 \\
\hline $\mathrm{C}_{15: 1} \omega 6 c$ & 3.4 & ND & ND & 1.6 & $\mathrm{ND}$ \\
\hline $\mathrm{C}_{16: 0}$ & $\mathrm{ND}$ & 3.5 & 5.9 & 1.2 & 6.0 \\
\hline iso- $\mathrm{C}_{16: 0}$ & 9.3 & 2.3 & 2.1 & 1.8 & 2.9 \\
\hline $\mathrm{C}_{16: 0} 3-\mathrm{OH}$ & 2.0 & ND & ND & $\mathrm{ND}$ & 1.6 \\
\hline iso- $\mathrm{C}_{16: 0} 3-\mathrm{OH}$ & 2.4 & ND & ND & $\operatorname{Tr}$ & $\mathrm{ND}$ \\
\hline iso- $\mathrm{C}_{16: 1} \mathrm{H}$ & 6.1 & $\mathrm{ND}$ & $\mathrm{ND}$ & $\operatorname{Tr}$ & $\mathrm{ND}$ \\
\hline $\mathrm{C}_{16: 1} \omega 5 c$ & 2.8 & ND & ND & 2.4 & 8.9 \\
\hline $\mathrm{C}_{17: 0} 2-\mathrm{OH}$ & 1.1 & $\mathrm{ND}$ & $\mathrm{ND}$ & $\mathrm{ND}$ & $\mathrm{ND}$ \\
\hline iso- $\mathrm{C}_{17: 0}$ & $\mathrm{ND}$ & 3.5 & ND & 1.4 & 1.8 \\
\hline anteiso- $\mathrm{C}_{17: 0}$ & $\mathrm{ND}$ & $\mathrm{ND}$ & 3.1 & $\operatorname{Tr}$ & $\mathrm{ND}$ \\
\hline iso- $\mathrm{C}_{17: 0} 3-\mathrm{OH}$ & 5.0 & 8.2 & ND & 8.9 & 6.5 \\
\hline $\mathrm{C}_{17: 1} \omega 6 c$ & 2.8 & ND & ND & 1.4 & 3.98 \\
\hline iso- $\mathrm{C}_{17: 1} \omega 9 c$ & 5.4 & 17.6 & ND & ND & 9.5 \\
\hline anteiso- $\mathrm{C}_{17: 1} \omega 9 c$ & ND & ND & 1.2 & ND & $\mathrm{ND}$ \\
\hline $\mathrm{C}_{18: 0}$ & $\mathrm{ND}$ & ND & 1.6 & ND & $\mathrm{ND}$ \\
\hline iso- $\mathrm{C}_{18: 0}$ & $\mathrm{ND}$ & ND & ND & 1.5 & $\mathrm{ND}$ \\
\hline \multicolumn{6}{|l|}{ Summed features ${ }^{\star}$} \\
\hline 3 & 5.9 & 3.3 & 4.9 & 3.7 & 20.2 \\
\hline 4 & ND & ND & ND & 1.4 & $\mathrm{ND}$ \\
\hline 9 & $\mathrm{ND}$ & ND & ND & 2.7 & $\mathrm{ND}$ \\
\hline
\end{tabular}

*Summed features represent groups of two or three fatty acids that cannot be separated by GLC with the MIDI system. Summed feature 3 contains $\mathrm{C}_{16: 1} \omega 7 c$ and/or $\mathrm{C}_{16: 1} \omega 6 c$; summed feature 4 contains iso- $\mathrm{C}_{17: 1} \mathrm{I}$ and/or anteiso- $\mathrm{C}_{17: 1} \mathrm{~B}$; summed feature 9 contains $\mathrm{C}_{16: 0}$ 10-methyl and/or iso- $\mathrm{C}_{17: 1} \omega 9 c$.

unidentified lipids (L1, L2, L7-L9, L11, L13-L15) (Fig. S1, available in IJSEM Online). A. balticum DSM $16537^{\mathrm{T}}$ possessed $\mathrm{PE}$, one unidentified aminophospholipid and five unidentified lipids. The DNA G + C content of strain $\mathrm{LW}^{\mathrm{T}}$ was $40.5 \mathrm{~mol} \%$ (Table 1 ).

Strain $\mathrm{LW}^{\mathrm{T}}$ could be differentiated from its closest phylogenetic neighbours by several traits such as oxidase activity, nitrate reduction, salt tolerance, hydrolysis of gelatin and starch, fatty acid and polar lipid composition and DNA G $+\mathrm{C}$ content (Tables 1 and 2 and Fig. S1). 
Hence, the combination of phenotypic properties and phylogenetic inference unambiguously supports the proposal of a novel species in a new genus in the family Cyclobacteriaceae for which the name Cecembia lonarensis gen. nov., sp. nov. is proposed.

\section{Description of Cecembia gen. nov.}

Cecembia [Ce.cem'bi.a. N.L. fem. n. Cecembia arbitrary name derived from the abbreviation CCMB (Centre for Cellular and Molecular Biology)].

Cells are Gram-staining-negative, strictly aerobic rods, catalase-positive and oxidase-negative. Carotenoid pigments are produced. The major fatty acids are iso- $\mathrm{C}_{15: 0}$, iso- $\mathrm{C}_{16: 0}$, anteiso- $\mathrm{C}_{15: 0}$, iso- $\mathrm{C}_{16: 1} \mathrm{H}$, summed feature 3 (comprising $\mathrm{C}_{16: 1} 107 c / \mathrm{C}_{16: 1} \omega 6 c$ ), iso- $\mathrm{C}_{17: 1} \omega 9 c$ and iso$\mathrm{C}_{17: 0} 3-\mathrm{OH}$. MK-7 is the only respiratory quinone. The polar lipids consist of PE, two unidentified aminolipids and seven unidentified lipids. The genus is affiliated to the family Cyclobacteriaceae. The type species is Cecembia lonarensis.

\section{Description of Cecembia lonarensis sp. nov.}

Cecembia lonarensis (lo.na.ren'sis. N.L. fem. adj. lonarensis of or belonging to Lonar lake, referring to the isolation source of the type strain).

The main characteristics are the same as those given for the genus. In addition, cells are non-motile rods, $0.5-0.6 \mu \mathrm{m}$ wide and 1.5-3.0 $\mu \mathrm{m}$ long, occurring singly, and multiply by binary fission. Colonies on half-strength marine agar are circular, 2-3 $\mathrm{mm}$ in diameter, smooth, reddish orange, translucent and raised with entire margins. Grows at 10 to $40{ }^{\circ} \mathrm{C}$ with an optimum temperature of $30-37^{\circ} \mathrm{C}$. Tolerates $0-4 \%(\mathrm{w} / \mathrm{v}) \mathrm{NaCl}$ and exhibits optimum growth in the presence of $2 \%(\mathrm{w} / \mathrm{v}) \mathrm{NaCl}$. Grows at $\mathrm{pH} 7.5-10.0$, with optimum growth at $\mathrm{pH}$ 8.0. Ornithine decarboxylase and lysine decarboxylase activities are present but urease, $\beta$-galactosidase, arginine dihydrolase and tryptophan deaminase activities are absent. The methyl red and VogesProskauer reactions are negative. Starch, aesculin, Tween 60, Tween 80 and gelatin are not hydrolysed. Nitrate is not reduced and $\mathrm{H}_{2} \mathrm{~S}$ gas is not produced. Produces acid from D-xylose, maltose, D-fructose, L-arabinose, cellobiose, D-glucose, D-mannose, methyl $\alpha$-D-glucoside, methyl $\alpha$-D-mannoside, melibiose, glycogen, creatinine, ornithine, starch, sorbose, citric acid, sodium gluconate, pyruvic acid, cellulose, rhamnose, erythritol, adonitol, inositol, D-mannitol and raffinose after 1 week of incubation at optimum temperature and $\mathrm{pH}$. Assimilates adonitol, lactose, xylose, maltose, fructose, glucose, raffinose, melibiose, sucrose, Larabinose, mannose, rhamnose, cellobiose, D-arabinose, citrate and malonate but not galactose, trehalose, inulin, sodium gluconate, glycerol, salicin, glucosamine, dulcitol, inositol, sorbitol, mannitol, methyl $\alpha$-D-glucoside, ribose, melezitose, methyl $\alpha$-D-mannoside, xylitol, sorbose or amygdalin. Susceptible to ( $\mu$ g per disc unless indicated) co-trimoxazole (25), lincomycin (2), nalidixic acid (30), ampicillin (10), bacitracin (10), carbenicillin (100), cefotaxime (30), chloramphenicol (30), ciprofloxacin (5), erythromycin (15), gentamicin (30), lomefloxacin (30), nitrofurantoin (300), norfloxacin (10), novobiocin (30), oleandomycin (15), penicillin G (10), rifampicin (30), spectinomycin (100), tetracycline (30), doxycycline (10), cefuroxime (30), cefoperazone (75), roxithromycin (30), streptomycin (10) and vancomycin (30) and resistant to amikacin (30), cefazolin (30), colistin (10), polymixin B (50 units/disc), kanamycin (30) and tobramycin (10). The polar lipids comprise PE, two unidentified aminolipids (AL1, AL2) and seven unidentified lipids (L1-L7). The complete fatty acid composition is given in Table 2.

The type strain is $\mathrm{LW} 9^{\mathrm{T}}\left(=\right.$ CCUG $58316^{\mathrm{T}}=$ KCTC $\left.22772^{\mathrm{T}}\right)$, isolated from a water sample collected at a depth of $4.5 \mathrm{~m}$ from haloalkaline Lonar Lake, Lonar, Buldhana district, Maharashtra, India. The DNA G $+\mathrm{C}$ content of the type strain is $40.5 \mathrm{~mol} \%$.

\section{Emended description of the genus Indibacter Anil Kumar et al. 2010}

The description is as given previously (Anil Kumar et al., 2010a) with the following modifications. The major fatty acids are iso- $\mathrm{C}_{15: 0}$, iso- $\mathrm{C}_{17: 1} \omega 9 c$, iso- $\mathrm{C}_{17: 0} 3-\mathrm{OH}$ and anteiso- $\mathrm{C}_{15: 0}$. The polar lipids consist of $\mathrm{PE}$, one unidentified aminolipid and five unidentified lipids. The type species is Indibacter alkaliphilus.

\section{Emended description of the genus Nitritalea Anil Kumar et al. 2010}

The description is as given previously (Anil Kumar et al., 2010b) with the addition that the polar lipids consist of PE, one unidentified aminolipid, two unidentified phospholipids and six unidentified lipids.

\section{Emended description of the genus Belliella Brettar et al. 2004}

The description is as given previously (Brettar et al., 2004a) with the following modifications. The major fatty acids are iso- $\mathrm{C}_{15: 0}, \mathrm{C}_{16: 1} \omega 7 c / \mathrm{C}_{16: 1} \omega 6 c$, iso- $\mathrm{C}_{17: 1} \omega 9 c$, $\mathrm{C}_{16: 1} \omega 5 c$, iso- $\mathrm{C}_{15: 1} \mathrm{G}$, iso- $\mathrm{C}_{17: 0} 3-\mathrm{OH}$ and $\mathrm{C}_{16: 0}$. MK-7 is the only respiratory quinone. The polar lipids consist of $\mathrm{PE}$, two unidentified phospholipids and nine unidentified lipids.

\section{Acknowledgements}

S. Shivaji is thankful to the National Centre for Antarctic and Ocean Research, Goa, Department of Biotechnology, New Delhi, and the CSIR Network Project on Exploitation of India's rich microbial diversity (NWP0006) for funding. T.N. R.S. acknowledges the CSIR, Government of India, for the award of a Research Associateship. 


\section{References}

Altschul, S. F., Gish, W., Miller, W., Myers, E. W. \& Lipman, D. J. (1990). Basic local alignment search tool. J Mol Biol 215, 403410.

Anil Kumar, P., Srinivas, T. N. R., Madhu, S., Manorama, R. \& Shivaji, S. (2010a). Indibacter alkaliphilus gen. nov., sp. nov., an alkaliphilic bacterium isolated from a haloalkaline lake. Int J Syst Evol Microbiol 60, 721-726.

Anil Kumar, P., Srinivas, T. N. R., Pavan Kumar, P., Madhu, S. \& Shivaji, S. (2010b). Nitritalea halalkaliphila gen. nov., sp. nov., an alkaliphilic bacterium of the family 'Cyclobacteriaceae', phylum Bacteroidetes. Int J Syst Evol Microbiol 60, 2320-2325.

Asker, D., Beppu, T. \& Ueda, K. (2007). Unique diversity of carotenoid-producing bacteria isolated from Misasa, a radioactive site in Japan. Appl Microbiol Biotechnol 77, 383-392.

Bligh, E. G. \& Dyer, W. J. (1959). A rapid method of total lipid extraction and purification. Can J Biochem Physiol 37, 911-917.

Bowman, J. P., Nichols, C. M. \& Gibson, J. A. (2003). Algoriphagus ratkowskyi gen. nov., sp. nov., Brumimicrobium glaciale gen. nov., sp. nov., Cryomorpha ignava gen. nov., sp. nov. and Crocinitomix catalasitica gen. nov., sp. nov., novel flavobacteria isolated from various polar habitats. Int J Syst Evol Microbiol 53, 1343-1355.

Brettar, I., Christen, R. \& Höfle, M. G. (2004a). Belliella baltica gen. nov., sp. nov., a novel marine bacterium of the CytophagaFlavobacterium-Bacteroides group isolated from surface water of the central Baltic Sea. Int J Syst Evol Microbiol 54, 65-70.

Brettar, I., Christen, R. \& Höfle, M. G. (2004b). Aquiflexum balticum gen. nov., sp. nov., a novel marine bacterium of the CytophagaFlavobacterium-Bacteroides group isolated from surface water of the central Baltic Sea. Int J Syst Evol Microbiol 54, 2335-2341.

Chun, J., Lee, J.-H., Jung, Y., Kim, M., Kim, S., Kim, B. K. \& Lim, Y. W. (2007). EzTaxon: a web-based tool for the identification of prokaryotes based on $16 \mathrm{~S}$ ribosomal RNA gene sequences. Int J Syst Evol Microbiol 57, 2259-2261.

Collins, M. D., Pirouz, T., Goodfellow, M. \& Minnikin, D. E. (1977). Distribution of menaquinones in actinomycetes and corynebacteria. J Gen Microbiol 100, 221-230.

Copa-Patiño, J. L., Arenas, M., Soliveri, J., Sánchez-Porro, C. \& Ventosa, A. (2008). Algoriphagus hitonicola sp. nov., isolated from an athalassohaline lagoon. Int J Syst Evol Microbiol 58, 424-428.

Felsenstein, J. (1993). PHYLIP (phylogeny inference package) version 3.5.1. Distributed by the author. Department of Genome Sciences, University of Washington, Seattle, USA.

Groth, I., Schumann, P., Rainey, F. A., Martin, K., Schuetze, B. \& Augsten, K. (1997). Demetria terragena gen. nov., sp. nov., a new genus of actinomycetes isolated from compost soil. Int J Syst Bacteriol 47, 1129-1133.

Guindon, S., Lethiec, F., Duroux, P. \& Gascuel, O. (2005). PHYML Online-a web server for fast maximum likelihood-based phylogenetic inference. Nucleic Acids Res 33 (Web Server issue), W557-W559.

Kimura, M. (1980). A simple method for estimating evolutionary rates of base substitutions through comparative studies of nucleotide sequences. J Mol Evol 16, 111-120.

Komagata, K. \& Suzuki, K. (1987). Lipid and cell-wall analysis in bacterial systematics. Methods Microbiol 19, 161-207.

Lane, D. J. (1991). 16S/23S rRNA sequencing. In Nucleic Acid Techniques in Bacterial Systematics, pp. 115-175. Edited by E. Stackebrandt \& M. Goodfellow. Chichester: Wiley.

Lányí, B. (1987). Classical and rapid identification methods for medically important bacteria. Methods Microbiol 19, 1-67.
Liu, Y., Li, H., Jiang, J. T., Liu, Y. H., Song, X. F., Xu, C. J. \& Liu, Z. P. (2009). Algoriphagus aquatilis sp. nov., isolated from a freshwater lake. Int J Syst Evol Microbiol 59, 1759-1763.

Ludwig, W., Euzéby, J. \& Whitman, W. B. (2008). Draft taxonomic outline of the Bacteroidetes, Planctomycetes, Chlamydiae, Spirochaetes, Fibrobacteres, Fusobacteria, Acidobacteria, Verrucomicrobia, Dictyoglomi, and Gemmatimonadetes for Volume 4 of the second edition of Bergey's Manual of Systematic Bacteriology (http://www.bergeys.org/outlines. html).

Marmur, J. (1961). A procedure for the isolation of deoxyribonucleic acid from micro-organisms. J Mol Biol 3, 208-218.

Nedashkovskaya, O. I., Vancanneyt, M., Van Trappen, S., Vandemeulebroecke, K., Lysenko, A. M., Rohde, M., Falsen, E., Frolova, G. M., Mikhailov, V. V. \& Swings, J. (2004). Description of Algoriphagus aquimarinus sp. nov., Algoriphagus chordae sp. nov. and Algoriphagus winogradskyi sp. nov., from sea water and algae, transfer of Hongiella halophila Yi and Chun 2004 to the genus Algoriphagus as Algoriphagus halophilus comb. nov. and emended descriptions of the genera Algoriphagus Bowman et al. 2003 and Hongiella Yi and Chun 2004. Int J Syst Evol Microbiol 54, 1757-1764.

Nedashkovskaya, O. I., Kim, S. B., Lee, M. S., Park, M. S., Lee, K. H., Lysenko, A. M., Oh, H. W., Mikhailov, V. V. \& Bae, K. S. (2005). Cyclobacterium amurskyense sp. nov., a novel marine bacterium isolated from sea water. Int J Syst Evol Microbiol 55, 2391-2394.

Nedashkovskaya, O. I., Kim, S. B., Vancanneyt, M., Lysenko, A. M., Shin, D. S., Park, M. S., Lee, K. H., Jung, W. J., Kalinovskaya, N. I. \& other authors (2006). Echinicola pacifica gen. nov., sp. nov., a novel flexibacterium isolated from the sea urchin Strongylocentrotus intermedius. Int J Syst Evol Microbiol 56, 953-958.

Nedashkovskaya, O. I., Kim, S. B., Kwon, K. K., Shin, D. S., Luo, X., Kim, S. J. \& Mikhailov, V. V. (2007). Proposal of Algoriphagus vanfongensis sp. nov., transfer of members of the genera Hongiella Yi and Chun 2004 emend. Nedashkovskaya et al. 2004 and Chimaereicella Tiago et al. 2006 to the genus Algoriphagus, and emended description of the genus Algoriphagus Bowman et al. 2003 emend. Nedashkovskaya et al. 2004. Int J Syst Evol Microbiol 57, 1988-1994.

Raj, H. D. \& Maloy, S. R. (1990). Proposal of Cyclobacterium marinus gen. nov., comb. nov., for a marine bacterium previously assigned to the genus Flectobacillus. Int J Syst Bacteriol 40, 337-347.

Saitou, N. \& Nei, M. (1987). The neighbor-joining method: a new method for reconstructing phylogenetic trees. Mol Biol Evol 4, 406-425.

Sly, L. I., Blackall, L. L., Kraat, P. C., Tian-Shen, T. \& Sangkhobol, V. (1986). The use of second derivative plots for the determination of mol\% guanine plus cytosine of DNA by the thermal denaturation method. J Microbiol Methods 5, 139-156.

Smibert, R. M. \& Krieg, N. R. (1994). Phenotypic characterization. In Methods for General and Molecular Bacteriology, pp. 607-654. Edited by P. Gerhardt, R. G. E. Murray, W. A. Wood \& N. R. Krieg. Washington, DC: American Society for Microbiology.

Thompson, J. D., Gibson, T. J., Plewniak, F., Jeanmougin, F. \& Higgins, D. G. (1997). The CLUSTAL_X windows interface: flexible strategies for multiple sequence alignment aided by quality analysis tools. Nucleic Acids Res 25, 4876-4882.

Van Trappen, S., Vandecandelaere, I., Mergaert, J. \& Swings, J. (2004). Algoriphagus antarcticus sp. nov., a novel psychrophile from microbial mats in Antarctic lakes. Int J Syst Evol Microbiol 54, 19691973.

Yi, H. \& Chun, J. (2004). Hongiella mannitolivorans gen. nov., sp. nov., Hongiella halophila sp. nov. and Hongiella ornithinivorans sp. nov., isolated from tidal flat sediment. Int J Syst Evol Microbiol 54, 157-162.

Ying, J. Y., Wang, B. J., Yang, S. S. \& Liu, S. J. (2006). Cyclobacterium lianum sp. nov., a marine bacterium isolated from sediment of an 
oilfield in the South China Sea, and emended description of the genus Cyclobacterium. Int J Syst Evol Microbiol 56, 2927-2930.

Yoon, J. H., Kang, S. J. \& Oh, T. K. (2005). Algoriphagus locisalis sp. nov., isolated from a marine solar saltern. Int J Syst Evol Microbiol 55, $1635-1639$.
Yoon, J. H., Lee, M. H., Kang, S. J. \& Oh, T. K. (2006). Algoriphagus terrigena sp. nov., isolated from soil. Int J Syst Evol Microbiol 56, 777780.

ZoBell, C. E. (1941). Studies on marine bacteria. I. The cultural requirements of heterotrophic aerobes. J Mar Res 4, 42-75. 